Published in final edited form as:

Eur J Pharmacol. 2006 October 10; 547(1-3): 92-100.

\title{
Effects of the selective delta opioid agonist SNC80 on cocaine- and food-maintained responding in rhesus monkeys
}

\author{
Gail Pereira Do Carmo ${ }^{a}$, Nancy K. Mello ${ }^{a}$, Kenner C. Rice ${ }^{b}$, John E. Folk ${ }^{a}$, and S. Stevens \\ Negus ${ }^{a},{ }^{*}$ \\ a Alcohol and Drug Abuse Research Center, McLean Hospital — Harvard Medical School, Belmont, \\ MA 02478, USA \\ b Laboratory of Medicinal Chemistry, NIDDK, National Institutes of Health, Bethesda, MD 20892, \\ USA
}

\begin{abstract}
Delta agonists such as SNC80 ((+)-4-[(aR)-a-((2S,5R)-4-allyl-2,5-dimethyl-1-piperazinyl)-3methoxybenzyl]- $N, N$-diethylbenzamide) produce some cocaine-like behavioral effects and warrant evaluation as candidate "agonist" medications for cocaine abuse. The present study examined acute and chronic effects of the systemically active delta agonist SNC80 on cocaine- and food-maintained responding in rhesus monkeys. Acute SNC80 $(0.32-3.2 \mathrm{mg} / \mathrm{kg}$, i.m. $)$ pretreatment dose-dependently decreased cocaine self-administration $(0.0032 \mathrm{mg} / \mathrm{kg} /$ injection $)$, but doses of SNC 80 that decreased cocaine self-administration also decreased food-maintained responding. In chronic studies, SNC80 $(0.32-3.2 \mathrm{mg} / \mathrm{kg} / \mathrm{h}$, i.v. $)$ was delivered for 7 days, and food or cocaine $(0.01 \mathrm{mg} / \mathrm{kg} / \mathrm{injection})$ was available during 4 daily components of food availability and 4 daily components of drug availability. Chronic SNC80 $(1.8 \mathrm{mg} / \mathrm{kg} / \mathrm{h})$ tended to decrease cocaine self-administration but produced greater reductions in food-maintained responding. A higher dose of $3.2 \mathrm{mg} / \mathrm{kg} / \mathrm{h} \mathrm{SNC} 80$ eliminated both cocaine- and food-maintained responding and produced profound sedation in one monkey and was not tested in other monkeys. These findings indicate that SNC80 produced dose-dependent and nonselective reductions in cocaine self-administration. These results suggest that SNC80 is unlikely to be useful as a treatment for cocaine dependence.
\end{abstract}

\section{Keywords}

Delta opioid receptor agonist; SNC80; Cocaine self-administration; (Rhesus monkey)

\section{Introduction}

Cocaine abuse is a widespread health problem in the United States and in other countries (SAMHSA, 2004). However, current pharmacotherapies have not been entirely effective in the treatment of cocaine abuse (Mendelson and Mello, 1996; Sofuoglu and Kosten, 2005; Vocci and Ling, 2005). Preclinical models of medication evaluation are designed to identify compounds that produce a sustained decrease in cocaine self-administration over a wide range of cocaine unit doses with minimal toxicity (Mello and Negus, 1996). One approach has focused on "agonist" medications that produce at least some effects similar to those of the target drug of abuse and which may prevent the emergence of abstinence signs during withdrawal from the abused drug (e.g., methadone for the treatment of opioid dependence; Mello and Negus, 1996). The abuse liability of cocaine is thought to result from its blockade of dopamine reuptake within the mesolimbic dopamine system (Kuhar et al., 1991; Wise,

\footnotetext{
*Corresponding author. Tel.: +1 617855 3324; fax: +1 617855 2519. E-mail address: negus@mclean.org (S.S. Negus).
} 
1998). In preclinical studies, long-acting and dopamine-selective monoamine releasers and uptake inhibitors such as amphetamine and GBR12909 have reliably reduced cocaine selfadministration, and these results have been interpreted to support the agonist approach to treatment of cocaine abuse and dependence (Rothman and Glowa, 1995; Negus and Mello, 2003a,b; Negus, 2003). However, preclinical and clinical data indicate that these agents have high abuse potential and may also produce other adverse effects (Carroll et al., 1999; Grabowski et al., 2004). Thus, an alternative approach has been to develop compounds that primarily target non-monoaminergic neurotransmitter systems but produce some cocaine-like effects.

Delta opioid receptor agonists are a class of compounds that warrants investigation. Delta opioid receptors are located in the nucleus accumbens and the striatum (Mansour et al., 1987), brain regions implicated in the reinforcing effects of cocaine. Like cocaine, centrally administered peptidic delta agonists increased extracellular dopamine in the nucleus accumbens (Spanagel et al., 1990; Longoni et al., 1991) and produced hyperactivity (Meyer, 1993). In drug discrimination assays, peptidic delta agonists were found to completely substitute for cocaine (Ukai et al., 1993; Suzuki et al., 1997). Peptidic delta agonists were also self-administered when injected into the ventral tegmental area or the nucleus accumbens and also induced conditioned place preference and reduced brain stimulation reward threshold intensities (Goeders et al., 1984; Shippenberg et al., 1987; Devine and Wise, 1994; Duvauchelle et al., 1997; Negus, 2004). However, the use of peptidic delta agonists is limited by poor biodistribution to the central nervous system when administered peripherally. An additional constraint is lack of receptor selectivity as many peptidic delta agonists demonstrate mu opioid receptor-mediated effects under some conditions (He and Lee, 1998; Fraser et al., 2000).

Systemically active, non-peptidic delta opioids have recently been developed and may offer more efficacious, receptor-selective alternatives to peptidic agonists. For example, the piperazinyl benzamide SNC80 is approximately 500-fold more selective for delta versus mu opioid receptors (Calderon et al., 1994; Bilsky et al., 1995). In rhesus monkeys, systemically administered (i.m.) SNC80 has a quick onset (10 min) and moderately long duration of action (100 min) and produces delta-selective antinociceptive effects (Negus et al., 1998; Brandt et al., 2001a). In drug discrimination studies with non-human primates, SNC80 partially or completely generalized to cocaine (Negus et al., 1998; Rowlett and Spealman, 1998), although this substitution was asymmetric in that cocaine did not substitute for SNC80 (Brandt et al., 1999). Further, SNC80 did not support self-administration over a broad range of behaviorally active doses and under conditions wherein cocaine functioned as a reinforcer (Negus et al., 1998). Taken together, these findings suggest that delta agonists in general, and SNC80 in particular, may produce some cocaine-like effects but have lower abuse liability than cocaine or other agonist medications that act directly on monoaminergic systems. To test the potential utility of delta agonists as agonist medications for cocaine dependence, the current study assessed the effects of acute and chronic SNC80 administration on cocaine- and foodmaintained responding in rhesus monkeys.

\section{Materials and methods}

\subsection{Subjects}

Four male and two female rhesus monkeys weighing 5-10 kg were used in studies to compare the acute and chronic effects of SNC80 on cocaine- and food-maintained responding. All monkeys had prior exposure to drugs (primarily dopaminergic and opioid compounds) and operant and behavioral procedures. The subjects were individually housed, and water was freely available. Their diet consisted of PMI Feeds Jumbo monkey diet (2-6 biscuits/day) and was supplemented with fresh fruit twice daily. A $12 \mathrm{~h}$ light/12 h dark cycle was in effect (lights on from 7 a.m. to 7 p.m.). All housing and procedures were in compliance with NIH guidelines 
on care and use of animal subjects in research, and were approved by the McLean Hospital Institutional Animal Care and Use Committee.

\subsection{Apparatus}

Experimental sessions were conducted in each monkey's home cage. The front wall was equipped with an operant panel $\left(28 \times 28 \mathrm{~cm}^{2}\right)$ that included three circular response keys $(5.1$ $\mathrm{cm}$ in diameter) arranged horizontally $2.5 \mathrm{~cm}$ apart. Each key could be transilluminated by red, green, or yellow stimulus lights (Superbright LEDs, St. Louis, MO). A food-pellet dispenser (Model G5210, Ralph Gerbrands, Arlington, MA) was mounted above each cage to deliver 1 $\mathrm{g}$ banana-flavored food pellets to a receptacle located below the operant panel. In addition, cages were also equipped with two infusion pumps (Model BSP-1, 5 RPM, Braintree Scientific, Braintree, MA; or Model PHM-100-5, Med Associates, St. Albans, VT) for delivery of saline or drug solutions through the two lumen of intravenous catheters. The schedules of reinforcement were controlled and data were collected with a computer and interface (MED Associates, Georgia, VT) located in a separate room.

For intravenous drug administration, a chronic double-lumen catheter was implanted into a jugular or femoral vein under aseptic conditions as described previously (Negus et al., 1995; Mello and Negus, 1998). One lumen (the "cocaine" lumen) was used for delivery of selfadministered cocaine injections. The second lumen (the "treatment" lumen) was used for delivery of saline or SNC80 (only during the chronic study). Each injection through the treatment lumen was delivered in $1 \mathrm{~s}$ in a volume of $0.1 \mathrm{ml}$, and injections were scheduled to occur every 20 min from 10:30 a.m. each day until 9:30 a.m. the next morning (i.e., $23 \mathrm{~h}$ per day for a total of 69 injections in $6.9 \mathrm{ml}$ ). No injections were delivered between 9:30 a.m. and 10:30 a.m. During this period, monkeys received their morning ration of food, and their health status was evaluated by the technical staff. Each monkey was fitted with a nylon vest attached to a flexible stainless-steel cable and a fluid swivel (Lomir Biomedical, Montreal, Canada) mounted to the top of the cage. The catheter was threaded through the cable and attached to one side of the fluid swivel. The other side of the fluid swivel was attached to the syringe pumps. Catheter patency was periodically evaluated by i.v. administration of ketamine $(5 \mathrm{mg} /$ $\mathrm{kg}$ ) or the short-acting barbiturate methohexital $(3 \mathrm{mg} / \mathrm{kg})$. The catheter was considered to be patent if administration of ketamine or methohexital produced a loss of muscle tone within 10 s.

\subsection{Acute effects of SNC80 on cocaine- and food-maintained responding}

2.3.1. Behavioral procedure-The acute effects of SNC $80(0.32-3.2 \mathrm{mg} / \mathrm{kg}$, i.m.) were evaluated in three male monkeys responding under a multiple schedule of cocaine and food reinforcement. This schedule has been used previously to access acute effects of candidate medication on cocaine- and food-maintained responding (Caine et al., 2000; Bowen et al., 2003). Sessions were conducted from 3 to 5 p.m. seven days per week, and each 2-h session consisted of three components. During the first and third components, food pellets were available under a fixed-ratio (FR) 30 schedule for $5 \mathrm{~min}$, and the center response key was transilluminated with a red stimulus light. During the second component, i.v. injections of saline- or cocaine were available under a FR 30 schedule for $100 \mathrm{~min}$, and the center response key was transilluminated with a green stimulus light. Session components were separated by 5-min time-out periods, during which all stimulus lights were off and responding had no scheduled consequences. The unit dose of cocaine available during the drug component of each session was determined by the concentration of drug in the syringe, and the syringe pumps were programmed to deliver $0.1 \mathrm{ml}$ in $1 \mathrm{~s}$. A 10-s time-out followed the completion of the ratio requirement for each food pellet or injection, and this time-out was signaled by the transillumination of the center response key with a yellow stimulus light. The second component (i.e., the drug component) was initiated by a 10-s transillumination of the center 
response key with a yellow stimulus light and the non-contingent delivery of a single 'priming' injection of the solution available for self-administration.

2.3.2. Training and testing procedures-Monkeys were initially trained to respond for food pellets and $0.032 \mathrm{mg} / \mathrm{kg} / \mathrm{injection}$ cocaine. Once cocaine self-administration stabilized during the drug component (three consecutive days with less than $20 \%$ variability in the mean number of injections), saline was substituted for cocaine until responding declined to less than 20 injections/day for three consecutive sessions. Thereafter, availability of cocaine $(0.032 \mathrm{mg} /$ $\mathrm{kg} /$ injection) and saline alternated across days, such that each solution was available for 1-3 days before alternating to the other solution. Training was considered to be complete when saline and the maintenance dose of $0.032 \mathrm{mg} / \mathrm{kg} /$ injections cocaine had each been available at least twice.

Test sessions lasted for one session and were conducted no more than twice each week. Test sessions were separated by at least two training sessions, during which the maintenance dose of $0.032 \mathrm{mg} / \mathrm{kg} /$ injection cocaine or saline was available during the drug component. In addition, test sessions always followed training sessions during which the cocaine maintenance dose was available. During test sessions, either no injection or an i.m. injection of SNC80 $(0.32-3.2 \mathrm{mg} / \mathrm{kg})$ was administered $15 \mathrm{~min}$ before the start of the session. In addition, the maintenance dose of cocaine was replaced with a test unit dose of cocaine $(0.00032-0.01 \mathrm{mg} /$ $\mathrm{kg} /$ injection). The unit dose of cocaine was altered by varying the concentration of cocaine in the syringe pump. Testing was conducted in two phases. In the first phase, the SNC80 dose was varied from 0.32 to $3.2 \mathrm{mg} / \mathrm{kg}$, and the unit dose of cocaine was held constant at 0.0032 $\mathrm{mg} / \mathrm{kg} / \mathrm{injection}$ (a dose at the peak of the cocaine self-administration dose-effect curve). In the second phase, the SNC80 dose was held constant at $3.2 \mathrm{mg} / \mathrm{kg}$, and the cocaine dose was varied $(0.00032-0.032 \mathrm{mg} / \mathrm{kg} /$ injection). The doses of SNC 80 were selected based on previous studies that examined effects of SNC80 on rates of food-maintained responding (Negus et al., 1998; Brandt et al., 2001a). The unit doses of cocaine were selected to span the ascending limb, peak and descending limb of the cocaine self-administration dose-effect curve.

2.3.3. Data analysis-The primary dependent variables were the numbers of food pellets or injections during the first food component (Food 1), the drug component, and the second food component (Food 2). In addition, for the first study in which SNC80 dose was varied and cocaine unit dose was held constant, rates of food- and cocaine-maintained reinforcement after SNC80 administration were expressed as the percent baseline rates of reinforcement observed with no injection. Data were analyzed by one- or two-factor analysis of variance (ANOVA). A significant ANOVA was followed by individual means comparisons using the Duncan post hoc test. The criterion for significance was set a priori at $P<0.05$.

\subsection{Chronic effects of SNC80 on cocaine- and food-maintained responding}

2.4.1. Behavioral procedure-The chronic effects of SNC 80 were assessed in one male and two female monkeys responding under a multiple-component, second-order schedule of cocaine and food reinforcement described previously (Mello and Negus, 1998; Negus and Mello, 2002). Under the terminal schedule, food components were conducted during each 24$\mathrm{h}$ period from 11 a.m. to noon, 3-4 p.m., 7-8 p.m. and 6-7 a.m. the next morning, whereas drug components were conducted one hour later from noon to 1 p.m., 4-5 p.m., 8-9 p.m. and 7-8 a.m. the next morning. Each component lasted for $1 \mathrm{~h}$ or until the delivery of 25 food pellets or 20 injections, whichever occurred first. The beginning of each component was signaled by onset of stimulus lights in the center response key (red for food, green for cocaine), and food pellets or cocaine injections were available under a second-order FR4 (VR16:S) schedule. Under this schedule, a variable ratio of 16 responses extinguished the stimulus lights in the center response key and illuminated a stimulus light beneath the response key (red for 
food, green for drug) for $1 \mathrm{~s}$. Completion of a fixed ratio of four VR response requirements resulted in the delivery of the available reinforcer and initiation of a 10-s timeout during which all stimulus lights were extinguished and responding had no scheduled consequences. If all available reinforcers were delivered prior to completion of the component, then stimulus lights were extinguished and responding had no scheduled consequences for the remainder of that component. For each 24-h period, the maximum number of food pellets/day was 100, and the maximum number of cocaine injections/day was 80 .

2.4.2. Training and testing procedures-Monkeys were initially trained to respond for food pellets and injections of $0.032 \mathrm{mg} / \mathrm{kg} /$ injection cocaine. Once cocaine self-administration stabilized during the drug components (three consecutive days with less than $20 \%$ variability in the mean number of injections/day), saline was substituted for cocaine for 7 days. Availability of $0.032 \mathrm{mg} / \mathrm{kg} / \mathrm{injection}$ cocaine was then reinstated until levels of drug selfadministration recovered to baseline levels. At this time, testing was initiated.

Test sessions were conducted for seven consecutive days. During these test sessions, the unit dose of cocaine available during drug components was changed to $0.01 \mathrm{mg} / \mathrm{kg} /$ injections, because previous studies demonstrated that this dose is located near the peak of the cocaine self-administration dose-effect curve in this procedure (Mello and Negus, 2000; Negus and Mello, 2002). The treatment solution, delivered through the lumen of the double lumen catheter, was either saline or SNC80 $(0.32-3.2 \mathrm{mg} / \mathrm{kg} / \mathrm{h})$. The doses of SNC 80 were determined empirically during the course of the study to span a range from ineffective doses to doses that produced undesirable effects. At the conclusion of each 7-day test, baseline conditions were reinstated $(0.032 \mathrm{mg} / \mathrm{kg} /$ injection cocaine with saline delivery through the treatment lumen $)$ for at least 4 days and until levels of cocaine self-administration recovered to baseline levels. The effects of treatment with saline and different doses of SNC80 were tested in an irregular order across monkeys. The highest dose of $3.2 \mathrm{mg} / \mathrm{kg} / \mathrm{h}$ SNC80 was tested for only two days in only one monkey due to severe sedative effects (see below).

2.4.3. Data analysis-The primary dependent variables were the numbers of food pellets/ day and cocaine injections/day delivered during the last three days of treatment with saline and each dose of SNC80. Values obtained during SNC80 treatment were then converted to percent baseline of the values obtained during saline treatment. Effects of SNC80 were analyzed by a two-factor ANOVA, with SNC80 dose and reinforcer type as the two factors. In addition, the effects of saline and $1.8 \mathrm{mg} / \mathrm{kg} / \mathrm{h} \mathrm{SNC} 80$ (the highest dose tested in all monkeys) are shown across all 7 days of treatment, with number of food pellets/day or drug injections/day as the dependent measure. For each reinforcer type, data were analyzed by two-factor ANOVA with type of treatment (saline or SNC80) and day of treatment as the two factors. A significant ANOVA was followed by individual means comparisons using the Duncan post hoc test. The criterion for significance was set a priori at $P<0.05$.

\subsection{Drugs}

Cocaine $\mathrm{HCl}$ (supplied by the National Institute on Drug Abuse, NIH, Bethesda, MD) was dissolved in sterile saline. SNC80 ((+)-4-[(aR)-a-((2S,5R)-4-allyl-2,5-dimethyl-1piperazinyl)-3-methoxybenzyl]- $N, N$-diethylbenzamide) supplied by K. Rice, NIDDK/NIH) was dissolved to a final concentration of $50 \mathrm{mg} / \mathrm{ml}$ in $3 \%$ lactic acid, and dilutions were made with sterile saline. Cocaine was delivered intravenously in a volume of $0.1 \mathrm{ml} /$ injection. SNC80 were administered intramuscularly into the thigh in a volume of $0.1-1 \mathrm{ml}$ for the acute studies, and intravenously in a volume of $0.1 \mathrm{ml} /$ injection in the chronic studies. All drugs for intravenous administration were filter-sterilized using a $0.22-\mu \mathrm{m}$ Millipore filter. 


\section{Results}

\subsection{Effects of acute SNC80 treatment}

Fig. 1 shows the effects of acute SNC $80(0.32-3.2 \mathrm{mg} / \mathrm{kg})$ on the percent control numbers of cocaine injections $(0.0032 \mathrm{mg} / \mathrm{kg} /$ injection) and food pellets delivered during the Drug and Food 1 components respectively. Results of the statistical analyses are described in the figure legend. The control numbers of reinforcers (mean \pm S.E.M.) were $90.6 \pm 18.6$ cocaine injections during the drug component and $16.7 \pm 2.7$ food pellets during the Food 1 component. SNC80 pretreatment produced dose-dependent decreases in cocaine self-administration. The higher SNC80 doses ( 1.0 and $3.2 \mathrm{mg} / \mathrm{kg}$ ) significantly decreased cocaine self-administration, whereas the low dose of SNC80 $(0.32 \mathrm{mg} / \mathrm{kg})$ did not. SNC80 also decreased food-maintained responding during the Food 1 component, but this effect was only significant with $3.2 \mathrm{mg} / \mathrm{kg}$ SNC80. There was no difference in the effects of SNC80 on cocaine- versus food-maintained responding. Responding during the Food 2 component was unaffected by SNC80 pretreatment (Table 1).

Fig. 2 shows the effects of acute $3.2 \mathrm{mg} / \mathrm{kg}$ SNC 80 on responding maintained by a broad range of cocaine doses during the drug component $(0.00032-0.01 \mathrm{mg} / \mathrm{kg} / \mathrm{injection})$ and food pellets during the Food 1 component (right panel). The cocaine self-administration dose-effect curve for injections/component had an inverted U-shape, with a unit dose of $0.0032 \mathrm{mg} / \mathrm{kg} /$ injection cocaine at the peak of the curve. SNC $80(3.2 \mathrm{mg} / \mathrm{kg})$ pretreatment produced a downward shift in the cocaine self-administration dose-effect curve and significantly decreased cocaine selfadministration at unit doses of 0.00032, 0.0032 and $0.01 \mathrm{mg} / \mathrm{kg} /$ injection. During the Food 1 component, $3.2 \mathrm{mg} / \mathrm{kg} \mathrm{SNC} 80$ decreased food-maintained responding during availability of unit doses of cocaine from 0.00032 to $0.01 \mathrm{mg} / \mathrm{kg} /$ injection. During the Food 2 component, the number of pellets earned in the presence or absence of SNC80 pretreatment did not significantly differ at any available unit dose of cocaine (Table 1).

\subsection{Effects of chronic SNC80 treatment}

Fig. 3 shows the mean data for the last three days of chronic SNC80 treatment $(0.32-3.2 \mathrm{mg} /$ $\mathrm{kg} / \mathrm{h})$ on responding maintained by food or cocaine $(0.01 \mathrm{mg} / \mathrm{kg} / \mathrm{injection})$. During saline treatment, monkeys earned $73.3 \pm 6.7$ cocaine injections/day and $79.8 \pm 10.1$ food pellets/day. Chronic treatment with $0.32-1.0 \mathrm{mg} / \mathrm{kg} / \mathrm{hr} \mathrm{SNC} 80$ did not significantly alter cocaine- or foodmaintained responding. A dose of $1.8 \mathrm{mg} / \mathrm{kg} / \mathrm{h} \mathrm{SNC} 80$ tended to decrease cocaine selfadministration and food-maintained responding. The highest dose of SNC80 $(3.2 \mathrm{mg} / \mathrm{kg} / \mathrm{h})$ was tested in only one monkey for two days. This treatment resulted in overt sedation (i.e., monkey laying on bottom of cage) and complete elimination of cocaine- and food-maintained responding. Because of these severe overt effects, this SNC80 dose was discontinued after two days of treatment and was not extended to the other monkeys in the study.

Fig. 4 shows the mean data for each of the 7 days of treatment with saline and $1.8 \mathrm{mg} / \mathrm{kg} / \mathrm{h}$ SNC80. In general, monkeys responded for almost the maximum number of cocaine injections/ day and food pellets/day throughout the 7 days of saline treatment. As compared to saline controls, $1.8 \mathrm{mg} / \mathrm{kg} / \mathrm{h} \mathrm{SNC} 80$ tended to decrease cocaine $(0.01 \mathrm{mg} / \mathrm{kg} /$ injection $)$ selfadministration, but this effect was not significant on any day. Chronic SNC80 administration also tended to reduce food-maintained responding. This effect was significant on Days 4, 5 and 6 of treatment.

\section{Discussion}

The main finding of the present study is that acute administration of the delta opioid receptor agonist SNC80 produced a dose-dependent decrease in cocaine self-administration across a broad range of cocaine unit doses in rhesus monkeys. However, SNC80 doses that decreased 
cocaine self-administration also usually decreased food-maintained responding. Chronic administration of SNC80 also failed to produce a selective reduction in cocaine selfadministration in comparison to food-maintained responding. These results suggest that SNC80-induced decreases in cocaine self-administration reflect non-selective suppression of responding rather than selective reductions in the reinforcing effects of cocaine.

The doses of SNC80 used in the current studies were in the behaviorally active range and produced effects consistent with previous research showing that SNC80 exerts depressive effects on operant behavior in rhesus monkeys. For example, acute administration of 1.0 and $3.2 \mathrm{mg} / \mathrm{kg}$ SNC80 dose-dependently reduced response rates in assays of schedule-controlled responding for food presentation in rhesus monkeys (Brandt et al., 2001a; Negus et al., 1998). In the present study, acute SNC80 pretreatment reduced responding during both the first food component and the drug component, whereas responding during the second food component (which began 115 min after SNC80 administration) was not altered. These results suggest that SNC80 effects may have dissipated by the time of the second food component. In agreement with this conclusion, an earlier study of SNC80 effects on food-maintained responding found the effects of SNC80 to peak after $10 \mathrm{~min}$ and subside by $100 \mathrm{~min}$ (Negus et al., 1998). Given that long-acting medications may be optimal as therapeutic agents for drug abuse treatment (Carroll et al., 1999), the relatively short duration of action seen with acute SNC80 administration is one characteristic that may limit its usefulness as a candidate agonist medication for cocaine dependence.

Treatment medications for drug dependence are often administered chronically, and we have argued that preclinical studies should include evaluation of the effects of chronic treatment with candidate pharmacotherapies (Mello and Negus, 1996). Effective candidate medications should optimally produce sustained decreases in cocaine self-administration with minimal side effects during chronic administration. In the current studies, $1.8 \mathrm{mg} / \mathrm{kg} / \mathrm{h} \mathrm{SNC} 80$ produced sustained but non-significant decreases in cocaine self-administration, and reductions in foodmaintained responding were greater than reductions in cocaine self-administration. The highest dose of SNC80 (3.2 mg/kg/h) eliminated both cocaine- and food-maintained responding, but the study was terminated after only two days due to severity of sedation. Although acute SNC80 $(3.2-32 \mathrm{mg} / \mathrm{kg}$, i. m.) has been shown to decrease activity in non-human primates (Negus et al., 1998), the severity of sedation observed in the current study following chronic administration of $3.2 \mathrm{mg} / \mathrm{kg} / \mathrm{h} \mathrm{i}$. v. SNC 80 was greater than that previously observed with acute treatments. These findings demonstrate that SNC80 also failed to selectively decrease cocaine self-administration during chronic treatment.

To our knowledge, the present investigation is the first to assess the potential utility of delta opioid receptor agonists as candidate medications for the treatment of cocaine abuse. Behavioral and neurochemical studies have shown that SNC80 produces delta receptormediated effects in rhesus monkeys and has high intrinsic efficacy at delta receptors (Negus et al., 1998; Brandt et al., 2001a; Ko et al., 2003). Previous research has demonstrated that delta opioid receptor agonists produce dose-dependent decreases in food-maintained behavior, and the potency to decrease food-maintained responding correlated with affinity at delta opioid receptors (Negus et al., 1998). Therefore, SNC80-induced suppression of both cocaine- and food-maintained behavior in the current study suggests that the delta opioid system may play a minor role in modulating the reinforcing effects of cocaine in rhesus monkeys. This is further supported by findings from earlier studies examining the effects of the delta antagonist naltrindole on cocaine self-administration. Naltrindole did not alter cocaine self-administration in rats (de Vries et al., 1995) and produced variable and inconsistent effects on cocaine selfadministration and discrimination in rhesus monkeys (Negus et al., 1995). 
Delta opioid receptor agonists produce some cocaine-like behavioral effects in both rodents and non-human primates (Longoni et al., 1991; Meyer, 1993; Devine and Wise, 1994; Duvauchelle et al., 1997; Suzuki et al., 1997; Negus et al., 1998), and one rationale for conducting the present study was to assess the potential utility of delta opioid receptor agonists as candidate agonist medications for the treatment of cocaine abuse. The non-selective effects of SNC80 on cocaine- and food-maintained responding in the present study contrast with the more selective effects that have been obtained with candidate agonist medications that, like cocaine, act directly on monoaminergic transporters. For example, the dopamine-selective uptake inhibitor GBR12909 selectively decreased cocaine self-administration while having lesser effects on food-maintained responding across a broad range of conditions (Glowa et al., 1995a,b; Glowa and Fantegrossi, 1997). Moreover, treatment with a long-acting formulation of GBR12909 produced a sustained and selective decrease in cocaine self-administration for approximately 4 weeks (Glowa et al., 1996). Similarly, the dopamine/norepinephrine-selective releaser amphetamine also produced selective and sustained decreases in cocaine selfadministration across a broad range of conditions in rhesus monkeys (Negus, 2003; Negus and Mello, 2003a,b).

The findings from the present study also extend our previous research on cocaine-opioid interactions and the potential utility of opioid receptor agonists as medications for the treatment of cocaine abuse. There are three major types of opioid receptors - the delta, mu and kappa opioid receptors - and all three opioid receptor types are anatomically positioned to modulate the activity of neurons in the mesolimbic dopamine system (Mansour et al., 1987; Mansour et al., 1994). Activation of delta and mu receptors generally promotes dopaminergic tone in this system, whereas kappa receptor activation inhibits dopaminergic tone (Di Chiara and Imperato, 1988; Spanagel et al., 1992; Devine et al., 1993; Maisonneuve et al., 1994). Using procedures similar to those used in the present study to evaluate the delta opioid receptor agonist SNC80, we reported previously that a range of mu opioid receptor agonists selectively decreased cocaine self-administration while having lesser effects on food-maintained responding (Mello et al., 1992; Negus and Mello, 2002; Negus and Mello, 2004). The most selective reductions in cocaine self-administration were achieved with the low efficacy mu agonists buprenorphine, nalbuphine and butorphanol (Mello et al., 1992; Negus and Mello, 2002). Kappa agonists also decreased cocaine self-administration; however, doses of selective and high-efficacy kappa opioid receptor agonists that decreased cocaine self-administration also usually decreased food-maintained responding and produced other undesirable effects (Negus et al., 1997; Mello and Negus, 1998; Bowen et al., 2003). More selective reductions in cocaine self-administration were obtained with mixed-action agonists that act at both kappa and mu receptors (Negus et al., 1997; Mello and Negus, 1998; Bowen et al., 2003; but see Stevenson et al., 2004). Overall then, our studies have found that the most selective reductions in cocaine self-administration have been obtained with mu opioid receptor agonists (especially low-efficacy mu opioid receptor agonists) and mixed-action kappa-mu agonists. Conversely, selective kappa and delta agonists have produced non-selective decreases in cocaine self-administration.

In summary, the present results indicate that SNC80 has a short duration of action, produces non-selective effects on cocaine- and food-maintained responding, and induces adverse side effects that would be expected to limit its clinical utility for the treatment of cocaine dependence. Delta opioid receptor agonists are currently being evaluated for use in a variety of clinical applications such as analgesia and depression (Brandt et al., 2001b; Jutkiewicz and Woods, 2004; Narita and Suzuki, 2004; Ossipov et al., 2004). However, the current findings suggest that delta opioid receptor agonists may not be useful for treatment of cocaine abuse. 


\section{Acknowledgments}

This work was supported by Grants R01-DA 11460, R01-DA02519 and K05-DA 00101 and funding from the Intramural Program from the National Institute on Drug Abuse, National Institutes of Health. The authors would also like to thank Cara Sylvester for excellent technical assistance.

\section{References}

Bilsky EJ, Calderon SN, Wang T, Bernstein RN, Davis P, Hruby VJ, McNutt RW, Rothman RB, Rice KC, Porreca F. SNC 80, a selective, nonpeptidic and systemically active opioid delta agonist. J. Pharmacol. Exp. Ther 1995;273:359-366. [PubMed: 7714789]

Bowen CA, Negus SS, Zong R, Neumeyer JL, Bidlack JM, Mello NK. Effects of mixed-action kappa/ mu opioids on cocaine self-administration and cocaine discrimination by rhesus monkeys. Neuropsychopharmacology 2003;28:1125-1139. [PubMed: 12637953]

Brandt MR, Negus SS, Mello NK, Furness MS, Zhang X, Rice KC. Discriminative stimulus effects of the nonpeptidic delta-opioid agonist SNC80 in rhesus monkeys. J. Pharmacol. Exp. Ther 1999;290:1157-1164. [PubMed: 10454490]

Brandt MR, Furness MS, Rice KC, Fischer BD, Negus SS. Studies of tolerance and dependence with the delta-opioid agonist SNC80 in rhesus monkeys responding under a schedule of food presentation. J. Pharmacol. Exp. Ther 2001a;299:629-637. [PubMed: 11602675]

Brandt MR, Furness MS, Mello NK, Rice KC, Negus SS. Antinociceptive effects of delta-opioid agonists in rhesus monkeys: effects on chemically induced thermal hypersensitivity. J. Pharmacol. Exp. Ther 2001b;296:939-946. [PubMed: 11181927]

Caine SB, Negus SS, Mello NK. Effects of dopamine D(1-like) and D(2-like) agonists on cocaine selfadministration in rhesus monkeys: rapid assessment of cocaine dose-effect functions. Psychopharmacology (Berl.) 2000;148:41-51. [PubMed: 10663416]

Calderon SN, Rothman RB, Porreca F, Flippen-Anderson JL, McNutt RW, Xu H, Smith LE, Bilsky EJ, Davis P, Rice KC. Probes for narcotic receptor mediated phenomena. 19. Synthesis of (+)-4-[(alpha R)-alpha-((2S,5R)-4-allyl-2,5-dimethyl-1-piperazinyl)-3-methoxybenzyl]-N,N-diethylbenzamide (SNC 80): a highly selective, nonpeptide delta opioid receptor agonist. J. Med. Chem 1994;37:21252128. [PubMed: 8035418]

Carroll FI, Howell LL, Kuhar MJ. Pharmacotherapies for treatment of cocaine abuse: preclinical aspects. J. Med. Chem 1999;42:2721-2736. [PubMed: 10425082]

Devine DP, Wise RA. Self-administration of morphine, DAMGO, and DPDPE into the ventral tegmental area of rats. J. Neurosci 1994;14:1978-1984. [PubMed: 8158252]

Devine DP, Leone P, Pocock D, Wise RA. Differential involvement of ventral tegmental mu, delta and kappa opioid receptors in modulation of basal mesolimbic dopamine release: in vivo microdialysis studies. J. Pharmacol. Exp. Ther 1993;266:1236-1246. [PubMed: 7690399]

de Vries TJ, Babovic-Vuksanovic D, Elmer G, Shippenberg TS. Lack of involvement of delta-opioid receptors in mediating the rewarding effects of cocaine. Psychopharmacology (Berl.) 1995;120:442448. [PubMed: 8539325]

Di Chiara G, Imperato A. Opposite effects of mu and kappa opiate agonists on dopamine release in the nucleus accumbens and in the dorsal caudate of freely moving rats. J. Pharmacol. Exp. Ther 1988;244:1067-1080. [PubMed: 2855239]

Duvauchelle CL, Fleming SM, Kornetsky C. DAMGO and DPDPE facilitation of brain stimulation reward thresholds is blocked by the dopamine antagonist cis-flupenthixol. Neuropharmacology 1997;36:1109-1114. [PubMed: 9294976]

Fraser GL, Pradhan AA, Clarke PB, Wahlestedt C. Supraspinal antinociceptive response to [D-Pen(2,5)]enkephalin (DPDPE) is pharmacologically distinct from that to other delta-agonists in the rat. J. Pharmacol. Exp. Ther 2000;295:1135-1141. [PubMed: 11082450]

Glowa JR, Fantegrossi WE. Effects of dopaminergic drugs on food- and cocaine-maintained responding, IV. Continuous cocaine infusions. Drug Alcohol Depend 1997;45:71-79. [PubMed: 9179509]

Glowa JR, Wojnicki FHE, Matecka D, Bacher JD, Mansbach RS, Balster RL, Rice KC. Effects of dopamine reuptake inhibitors on food- and cocaine-maintained responding: I. Dependence on unit dose of cocaine. Exp. Clin. Psychopharmacol 1995a;3:219-231. 
Glowa JR, Wojnicki FHE, Matecka D, Bacher JD, Mansbach RS, Balster RL, Rice KC. Effects of dopamine uptake inhibitors on food- and cocaine-maintained responding: II. Comparisons with other drugs and repeated administration. Exp. Clin. Psychopharmacol 1995b;3:232-239.

Glowa JR, Fantegrossi WE, Lewis DB, Matecka D, Rice KC, Rothman RB. Sustained decrease in cocaine-maintained responding in rhesus monkeys with 1-[2-[bis(4-fluorophenyl)methoxy]ethyl]-4(3-hydroxy-3-phenylpropyl) piperazinyl decanoate, a long-acting ester derivative of GBR 12909. J. Med. Chem 1996;39:4689-4691. [PubMed: 8941381]

Goeders NE, Lane JD, Smith JE. Self-administration of methionine enkephalin into the nucleus accumbens. Pharmacol. Biochem. Behav 1984;20:451-455. [PubMed: 6324244]

Grabowski J, Shearer J, Merrill J, Negus SS. Agonist-like, replacement pharmacotherapy for stimulant abuse and dependence. Addict. Behav 2004;29:1439-1464. [PubMed: 15345275]

He L, Lee NM. Delta opioid receptor enhancement of mu opioid receptor-induced antinociception in spinal cord. J. Pharmacol. Exp. Ther 1998;285:1181-1186. [PubMed: 9618421]

Jutkiewicz, EM.; Woods, JH. Antidepressant-like effects in delta opioid receptor agonists. In: Chang, K.; Porreca, F.; Woods, JH., editors. The Delta Receptor. Marcel Dekker, Inc.; New York/Basel: 2004. p. 355-372.

Ko MC, Lee H, Harrison C, Clark MJ, Song HF, Naughton NN, Woods JH, Traynor JR. Studies of micro-, kappa-, and delta-opioid receptor density and G protein activation in the cortex and thalamus of monkeys. J. Pharmacol. Exp. Ther 2003;306:179-186. [PubMed: 12676881]

Kuhar MJ, Ritz MC, Boja JW. The dopamine hypothesis of the reinforcing properties of cocaine. Trends Neurosci 1991;14:299-302. [PubMed: 1719677]

Longoni R, Spina L, Mulas A, Carboni E, Garau L, Melchiorri P, Di Chiara G. (D-Ala2)deltorphin II: D1-dependent stereotypies and stimulation of dopamine release in the nucleus accumbens. J. Neurosci 1991;11:1565-1576. [PubMed: 1646295]

Maisonneuve IM, Archer S, Glick SD. U50,488, a kappa opioid receptor agonist, attenuates cocaineinduced increases in extracellular dopamine in the nucleus accumbens of rats. Neurosci. Lett 1994;181:57-60. [PubMed: 7898771]

Mansour A, Khachaturian H, Lewis ME, Akil H, Watson SJ. Autoradiographic differentiation of mu, delta, and kappa opioid receptors in the rat forebrain and midbrain. J. Neurosci 1987;7:2445-2464. [PubMed: 3039080]

Mansour A, Fox CA, Burke S, Meng F, Thompson RC, Akil H, Watson SJ. Mu, delta, and kappa opioid receptor mRNA expression in the rat CNS: an in situ hybridization study. J. Comp. Neurol 1994;350:412-438. [PubMed: 7884049]

Mello NK, Negus SS. Preclinical evaluation of pharmacotherapies for treatment of cocaine and opioid abuse using drug self-administration procedures. Neuropsychopharmacology 1996;14:375-424. [PubMed: 8726752]

Mello NK, Negus SS. Effects of kappa opioid agonists on cocaine-and food-maintained responding by rhesus monkeys. J. Pharmacol. Exp. Ther 1998;286:812-824. [PubMed: 9694938]

Mello NK, Negus SS. Interactions between kappa opioid agonists and cocaine. Preclinical studies. Ann. N. Y. Acad. Sci 2000;909:104-132.

Mello NK, Lukas SE, Kamien JB, Mendelson JH, Drieze J, Cone EJ. The effects of chronic buprenorphine treatment on cocaine and food self-administration by rhesus monkeys. J. Pharmacol. Exp. Ther 1992;260:1185-1193. [PubMed: 1545386]

Mendelson JH, Mello NK. Management of cocaine abuse and dependence. N. Engl. J. Med 1996;334:965-972. [PubMed: 8596599]

Meyer ME. Behavioral effects of opioid peptide agonists DAMGO, DPDPE, and DAKLI on locomotor activities. Pharmacol. Biochem. Behav 1993;45:315-320. [PubMed: 8392203]

Narita, M.; Suzuki, T. Delta opioid receptor-mediated antinociception/analgesia. In: Chang, K.; Porreca, F.; Woods, JH., editors. The Delta Receptor. Marcel Dekker, Inc.; New York/Basel: 2004. p. 331-354.

Negus SS. Rapid assessment of choice between cocaine and food in rhesus monkeys: effects of environmental manipulations and treatment with d-amphetamine and flupenthixol. Neuropsychopharmacology 2003;28:919-931. [PubMed: 12637948]

Negus, SS. Delta opioids and substance abuse. In: Chang, K.; Porreca, F.; Woods, JH., editors. The Delta Receptor. Marcel Dekker, Inc.; New York/Basel: 2004. p. 401-430. 
Negus SS, Mello NK. Effects of mu-opioid agonists on cocaine- and food-maintained responding and cocaine discrimination in rhesus monkeys: role of mu-agonist efficacy. J. Pharmacol. Exp. Ther 2002;300:1111-1121. [PubMed: 11861822]

Negus SS, Mello NK. Effects of chronic d-amphetamine treatment on cocaine- and food-maintained responding under a progressive-ratio schedule in rhesus monkeys. Psychopharmacology (Berl.) 2003a;167:324-332. [PubMed: 12652348]

Negus SS, Mello NK. Effects of chronic d-amphetamine treatment on cocaine- and food-maintained responding under a second-order schedule in rhesus monkeys. Drug Alcohol Depend 2003b;70:39_ 52. [PubMed: 12681524]

Negus SS, Mello NK. Effects of chronic methadone treatment on cocaine- and food-maintained responding under second-order, progressive-ratio and concurrent-choice schedules in rhesus monkeys. Drug Alcohol Depend 2004;74:297-309. [PubMed: 15194208]

Negus SS, Mello NK, Portoghese PS, Lukas SE, Mendelson JH. Role of delta opioid receptors in the reinforcing and discriminative stimulus effects of cocaine in rhesus monkeys. J. Pharmacol. Exp. Ther 1995;273:1245-1256. [PubMed: 7791097]

Negus SS, Mello NK, Portoghese PS, Lin CE. Effects of kappa opioids on cocaine self-administration by rhesus monkeys. J. Pharmacol. Exp. Ther 1997;282:44-55. [PubMed: 9223538]

Negus SS, Gatch MB, Mello NK, Zhang X, Rice K. Behavioral effects of the delta-selective opioid agonist SNC80 and related compounds in rhesus monkeys. J. Pharmacol. Exp. Ther 1998;286:362-375. [PubMed: 9655881]

Ossipov, MH.; Lai, J.; Vanderah, TW.; Porreca, F. The delta receptor subtypes and pain modulation. In: Chang, K.; Porreca, F.; Woods, JH., editors. The Delta Receptor. Marcel Dekker, Inc; New York/ Basel: 2004. p. 297

Rothman RB, Glowa JR. A review of the effects of dopaminergic agents on humans, animals, and drugseeking behavior, and its implications for medication development. Focus on GBR 12909. Mol. Neurobiol 1995;11:1-19. [PubMed: 8561954]

Rowlett JK, Spealman RD. Opioid enhancement of the discriminative stimulus effects of cocaine: evidence for involvement of mu and delta opioid receptors. Psychopharmacology (Berl.) 1998;140:217-224. [PubMed: 9860113]

SAMHSA. Results from the 2003 National Survey on Drug Abuse and Health: National findings, (Office of Applied Studies, NSDUH Series H-25 DHHS Publication No. SMA 04-3964). Rockville, MD: 2004.

Shippenberg TS, Bals-Kubik R, Herz A. Motivational properties of opioids: evidence that an activation of delta-receptors mediates reinforcement processes. Brain Res 1987;436:234-239. [PubMed: 2829990]

Sofuoglu M, Kosten TR. Novel approaches to the treatment of cocaine addiction. CNS Drugs 2005;19:1325. [PubMed: 15651902]

Spanagel R, Herz A, Shippenberg TS. The effects of opioid peptides on dopamine release in the nucleus accumbens: an in vivo microdialysis study. J. Neurochem 1990;55:1734-1740. [PubMed: 1976759]

Spanagel R, Herz A, Shippenberg TS. Opposing tonically active endogenous opioid systems modulate the mesolimbic dopaminergic pathway. Proc. Natl. Acad. Sci. U. S. A 1992;89:2046-2050. [PubMed: 1347943]

Stevenson GW, Wentland MP, Bidlack JM, Mello NK, Negus SS. Effects of the mixed-action kappa/mu opioid agonist 8-carboxamidocyclazocine on cocaine- and food-maintained responding in rhesus monkeys. Eur. J. Pharmacol 2004;506:133-141. [PubMed: 15588733]

Suzuki T, Mori T, Tsuji M, Maeda J, Kishimoto Y, Misawa M, Nagase H. Differential effects of mu-, delta- and kappa-opioid receptor agonists on the discriminative stimulus properties of cocaine in rats. Eur. J. Pharmacol 1997;324:21-29. [PubMed: 9137909]

Ukai M, Mori E, Kameyama T. Cocaine-like discriminative stimulus properties of the delta-selective opioid receptor agonist, [D-Pen2, L-Pen5] enkephalin, in the rat. Eur. J. Pharmacol 1993;231:143144. [PubMed: 8383062]

Vocci F, Ling W. Medications development: successes and challenges. Pharmacol. Ther 2005;108:94108. [PubMed: 16083966] 
Wise RA. Drug-activation of brain reward pathways. Drug Alcohol Depend 1998;51:13-22. [PubMed: 9716927] 


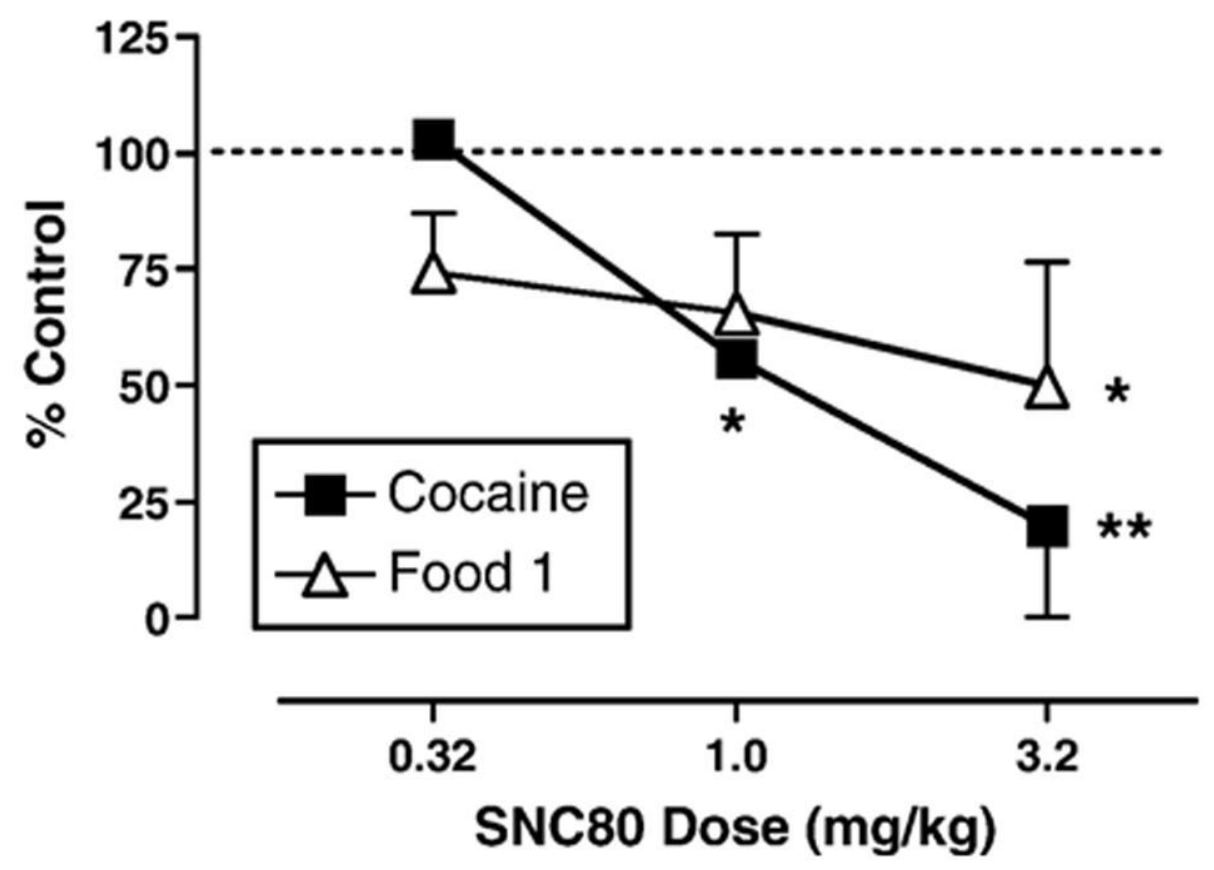

Fig. 1.

Acute effects of SNC80 $(0.32-3.2 \mathrm{mg} / \mathrm{kg}$, i.m.) on responding maintained by food during the first food component (Food 1) or by $0.0032 \mathrm{mg} / \mathrm{kg} /$ injection cocaine during the drug component. Abscissa: dose SNC80 in mg/kg i.m. administered $15 \mathrm{~min}$ before the session (log scale). Ordinate: percent control number of reinforcers earned during the Food 1 and cocaine components. The control numbers of reinforcers/component were 16.7 \pm 2.7 during the 5-min Food 1 component and 90.6 \pm 18.6 injections during the 100-min drug component. All points show mean data \pm S.E.M. from 3 rhesus monkeys. Two-factor ANOVA indicated a significant main effect of SNC80 dose $[F(2,6)=15.6, P=0.003]$ but not of reinforcer type $[F(2,2)=0.05$, $P=0.85]$, and there was no significant interaction between SNC80 dose or reinforcer type $[F$ $(3,6)=2.6, P=0.15]$. Asterisks indicate significantly different from control by Duncan post hoc $(* P<0.05, * * P<0.01)$. 
Cocaine

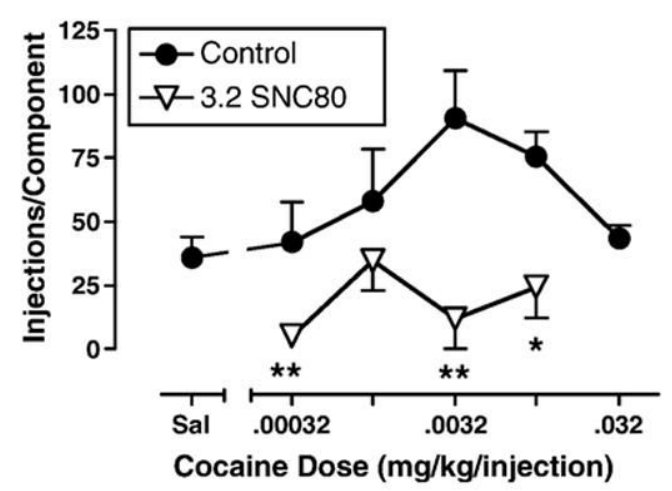

Food 1

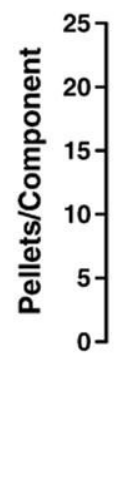

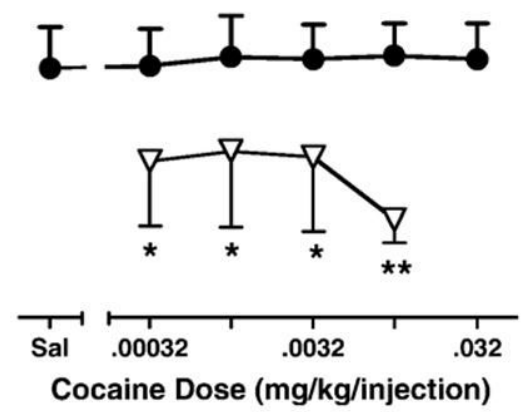

Fig. 2.

Acute effects of $3.2 \mathrm{mg} / \mathrm{kg}$ SNC80 on the cocaine self-administration dose-effect curve and on food-maintained responding during the Food 1 component. Abscissae: unit dose of cocaine available during the drug component (log scale). Ordinate (left panel): mean number of cocaine injections obtained during the drug component. Ordinate (right panel): mean number of food pellets earned during the first food component. All points show mean reinforcers \pm S.E.M. from 3 rhesus monkeys. Two-factor ANOVA for cocaine-maintained responding indicated significant effects of SNC80 dose $[F(2,2)=54.7, P=0.018]$ but not of cocaine unit dose $[F(2,6)$ $=1.2, P=0.39]$ or the interaction $[F(3,6)=1.2, P=0.39]$. Two-factor ANOVA for foodmaintained responding indicated a significant effect of SNC80 dose $[F(2,2)=18.4, P=0.05]$ but not of cocaine unit dose $[F(2,6)=1.1, P=0.42]$, and there was no significant interaction $[F(2,6)$ $=1.1, P=0.42]$. Asterisks indicate significantly different from control by Duncan post hoc $(* P<0.05, * * P<0.01)$. 


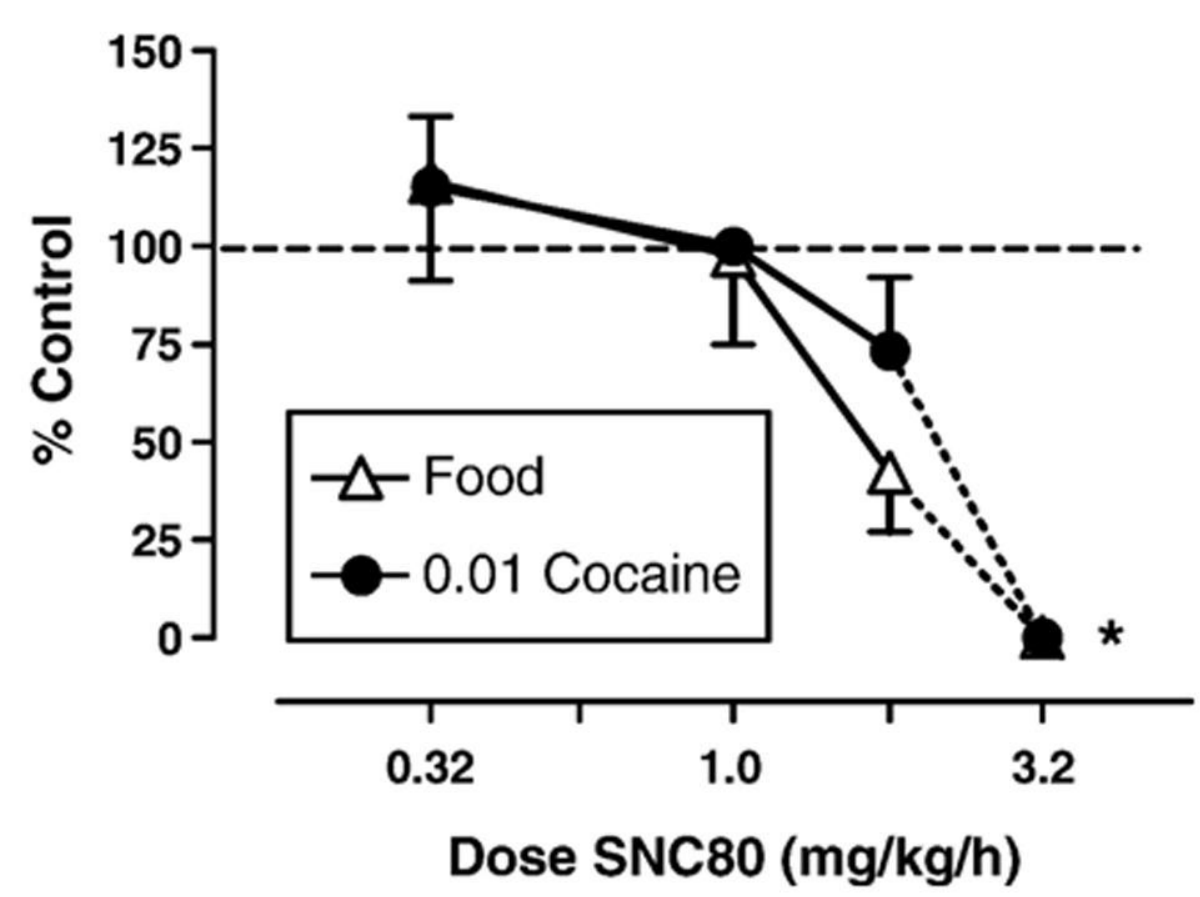

Fig. 3.

Chronic effects of SNC80 $(0.32-3.2 \mathrm{mg} / \mathrm{kg} / \mathrm{h})$ on responding maintained by food or cocaine ( $0.01 \mathrm{mg} / \mathrm{kg} /$ injection). Abscissa: dose SNC80 in mg/kg/h (log scale). Ordinate: percent control number of food pellets per day and cocaine injections per day. The control numbers of reinforcers/day were $79.8 \pm 10.1$ food pellets and $73.3 \pm 6.7$ cocaine injections. All points show mean data \pm S.E.M. obtained during the last three days of a 7-day treatment in three monkeys ( 1.0 and $1.8 \mathrm{mg} / \mathrm{kg} / \mathrm{h})$ or two monkeys $(0.32 \mathrm{mg} / \mathrm{kg} / \mathrm{h})$ except the points for $3.2 \mathrm{mg} / \mathrm{kg} / \mathrm{h} \mathrm{SNC} 80$, which show data for only two days of treatment in one monkey. The asterisk (*) indicates that this treatment was terminated after 2 days due to extreme sedation, and the monkey did not respond for any food pellets or drug injections during those two days. Other monkeys were not tested at this dose due to concerns about toxicity. Two-factor ANOVA for data at baseline, 1.0 and $1.8 \mathrm{mg} / \mathrm{kg} / \mathrm{h} \mathrm{SNC80}$ indicated that there was not a significant effect of reinforcer type $[F$ $(2,2)=0.76, P=0.48]$ or SNC80 dose $[F(2,4)=4.0, P=0.12]$, nor was there a significant interaction $[F(2,4)=2.1, P=0.23]$. 
Cocaine Self-Administration

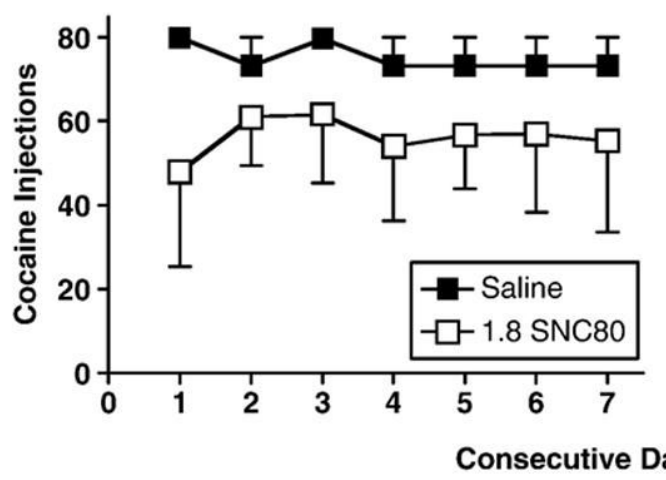

Food-Maintained Responding

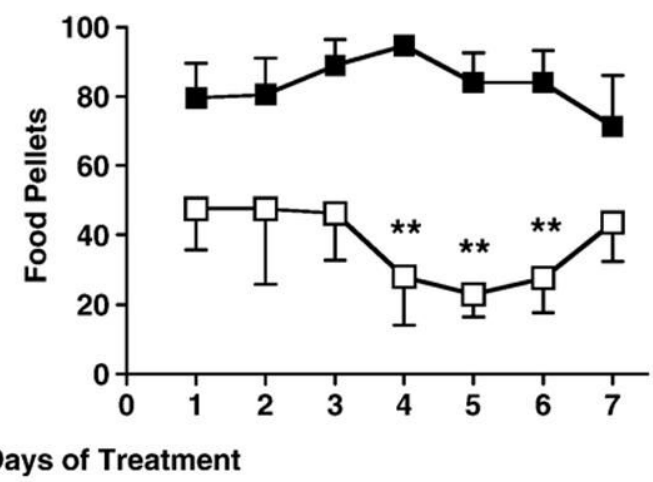

Fig. 4.

Time course effects of saline or SNC80 $(1.8 \mathrm{mg} / \mathrm{kg} / \mathrm{h})$ on responding maintained by food or cocaine $(0.01 \mathrm{mg} / \mathrm{kg} /$ injection). Abscissae: consecutive days of treatment. Ordinate (left panel): number of cocaine injections $(0.01 \mathrm{mg} / \mathrm{kg}$ per injection) delivered on each day of treatment. Ordinate (right panel): number of food pellets per day delivered on each day of treatment. Each point shows mean data \pm S.E.M. from three monkeys. Two-factor ANOVA for cocaine selfadministration indicated there was not a significant effect of SNC80 dose $[F(1,2)=12.341$, $P=0.27]$ or time $[F(2,6)=0.72, P=0.64]$, nor was there a significant interaction $[F(2,6)=0.72$, $P=0.64]$. Similarly, for food-maintained responding, two-factor ANOVA indicated no significant effects of SNC80 dose $[F(1,2)=16.154, P=0.57]$ or time $[F(2,6)=1.745, P=0.194]$ or interaction $[F(2,6)=1.745, P=0.194]$. However, analysis of simple effects shows a significant effect of SNC80 dose on Days 4, 5 and 6 of treatment. Asterisks indicate significantly different from controls by Duncan post hoc $(* * P<0.01)$. 
Table 1

Number food pellets ( \pm S.E.M.) delivered during the Food 2 component

\begin{tabular}{llr}
\hline Cocaine dose & SNC80 dose & Number of pellets $( \pm$ S.E.M.) \\
\hline 0.0032 & - & $17.1 \pm 2.2$ \\
0.0032 & 0.32 & $16.0 \pm 2.6$ \\
0.0032 & 1.0 & $15 . \pm 2.3$ \\
0.0032 & 3.2 & $16.4 \pm 1.7$ \\
0.00032 & - & $14.6 \pm 3.6$ \\
0.001 & - & $16.3 \pm 3.7$ \\
0.0032 & - & $17.6 \pm 2.6$ \\
0.01 & 3.2 & $14.6 \pm 3.1$ \\
0.00032 & 3.2 & $13.1 \pm 3.0$ \\
0.001 & 3.2 & $17.3 \pm 2.5$ \\
0.0032 & 3.2 & $16.4 \pm 1.7$ \\
0.01 & & $16.9 \pm 1.6$ \\
\hline
\end{tabular}

